\title{
In the beginning there was RNA, then came transcription regulation: the Nobel Prize Lectures 2006
}

\author{
G Melino $^{\star, 1,2}$, P Nicotera $^{1}$ and G Macino ${ }^{3}$ \\ Cell Death and Differentiation (2007) 14, 1975-1976; doi:10.1038/sj.cdd.4402259
}

In the beginning, there was only RNA.

Evolutionary simple organisms can survive and replicate using RNA as the only coding molecule. From the ancestral self-replicating RNA-world hypothesis, a complex machinery has evolved to maintain replication and transcription, ensuring not only the integrity of the genome, but also a correct translation of information into proteins. From a DNA-centric world where gene expression was primarily controlled by coding genes in the nucleus with RNA functioning as translator, we now understand the essential controlling role of RNA. Thanks to the generous concession of the Nobel Foundation (From Les Prix Nobel. The Nobel Prizes 2006, Editor Karl Grandin, [Nobel Foundation], Stockholm, 2007. Copyright (C) The Nobel Foundation 2006) here we report the original autobiographies ${ }^{1-2}$ of the scientists involved and their accounts of the discovery of the nucleosome and RNA interference (RNAi). ${ }^{3-5}$

The nucleosome is the basic unit of chromatin, and consists of 146 bp of DNA wrapped in two left-oriented superhelices on the external surface of an octamer of histone proteins. These include two copies of each core histones $\mathrm{H} 2 \mathrm{~A}, \mathrm{H} 2 \mathrm{~B}, \mathrm{H} 3$ and $\mathrm{H} 4$, with their fold domains necessary to mediate the histonehistone and histone-DNA interactions, which are required for both the assembly and stability of the nucleosome octamer and the regulated reading of the genetic information. $\mathrm{N}$-terminal tail domains are crucial for the nucleosome, for binding to other proteins such as linker histones and highmobility group proteins, and for posttranslational regulation. Examples of these interactions involve binding to kinases, phosphatases, histone acetyl transferases, histone methyltransferases, ubiquitin and SUMO protein ligases. Indeed, phosphorylation, ubiquitylation, methylation and acetylation are covalent histone modifications that regulate the function of the nucleosome. ${ }^{6}$ At the structural level, specific regions have been defined within nucleosome proteins, for example bromodomains, tudor domains, plant homodomains. But how has this complexity in chromatin structure and dynamics been identified? How have the molecular mechanisms that regulate transcription been elucidated? Here, we move from the original model by $\mathrm{Crick}^{7}$ through the specific contributions of Roger Kornberg, ${ }^{8-12}$ to the present degree of complexity. In addition to his original Nobel Lecture, ${ }^{3}$ his autobiography ${ }^{1}$ brings into the equation his personal life, full of hard work, excitement and the inevitable downsides.

Kornberg's biochemical techniques with structural investigations have enabled the atomic level reconstruction of RNA polymerase from yeast in isolation as well as in a number of functionally relevant complexes with template DNA, product mRNA, substrate nucleotides and regulatory proteins.

Kornberg entered the field of transcription when he worked on the structure of chromatin as a postdoctoral student at the Medical Research Council in Cambridge UK, in the Laboratory of Molecular Biology with Francis Crick and Aaron Klug. In his initial observation, he found that histones $\mathrm{H} 3$ and $\mathrm{H} 4$ in solution form a tetramer of the type $(\mathrm{H} 3)_{2}(\mathrm{H} 4)_{2},{ }^{11}$ and he also proposed that the basal unit of chromatin (the nucleosome) is a histone octamer with circa $200 \mathrm{bp}$ of DNA. ${ }^{9}$ In the following years, Dr Kornberg worked on the TATA-binding proteins, contributing to the identification of a large multiprotein complex, Mediator, and the understanding of the function of RNA polymerase II. The resolution of these complexes at the structural level provided information on promoter recognition, creating a basis for the understanding of the rest of the transcriptional apparatus. In 2001, he described the structure of a 10-subunit yeast RNA polymerase with an elongating complex (RNA polymerase, template DNA and product RNA). ${ }^{13,14}$ This was pivotal for the more recent work on translocation, strand separation and nucleotide selection. The mechanistic understanding of the transcription regulation in eukaryotes is a key to explain abortive initiation and promoter escape, that is, the pathology of transcription.

Is this the entire story? The central dogma of molecular biology, experimentally validated, indicated that cells mainly used double-stranded DNA and single-stranded RNA for longand short-term information storage, respectively. This left no place in normal cellular information flow for double-stranded RNA (dsRNA), while leaving a key role for it in replication of RNA viruses. This also indicated that the mechanisms regulating gene expression in the RNA world were lost. The revolutionary discovery pioneered by Fire and Mello caused a rethinking of this gene expression paradigm.

\footnotetext{
${ }^{1}$ Medical Research Council, Toxicology Unit, Hodgkin Building, Leicester University, Lancaster Road, PO Box 138, Leicester LE1 9HN, UK; ${ }^{2}$ Department of Experimental Medicine, University of Rome 'Tor Vergata', Rome 00133, Italy; ${ }^{3}$ Department of Cellular and Haematological Biotechnology, University of Rome 'La Sapienza', Rome 00161, Italy

*Correspondence: G Melino, P Nicotera, G, Macino, Cell Death and Differentiation, Rome Editorial Office, University of Rome, 'Tor Vergata', Via Montpellier 1, Rome 133, Italy. Tel: + 39062042 7299; Fax: + 39062042 7290; E-mails: cell.death.differ@uniroma2.it or gm89@le.ac.uk or pn10@le.ac.uk or macino@bce.uniroma1.it
} 
At its very early stages the story again involved the Laboratory of Molecular Biology of the Medical Research Council in Cambridge UK where, during his postdoctoral training, Fire carried out inspiring work on Caenorhabditis elegans. Indeed, the regulation of translation by antisense RNA in eukaryotes was initially demonstrated in this organism. In fact, prior to the formal discovery of RNAi by Fire and Mello, ${ }^{15}$ posttranscriptional gene silencing (PTGS) had been described in plants and other organisms. To mention an example, a PTGS-like process was identified in the fungus Neurospora crassa. ${ }^{16}$ Mello argued that the mechanism could not just be a pairing of antisense RNA to mRNA, coining the term RNAi for the unknown mechanism, ${ }^{17}$ demonstrating that dsRNA exerts its effect at the posttranscriptional level. ${ }^{18}$ The work by Fire and Mello explained the PTGS previously observed in plants. The molecular machinery involved in RNAi was subsequently elucidated with the discovery of the RNA-induced silencing complex, RISC, the identification of the argonaute protein family, and the ribonuclease III-like nuclease, Dicer, responsible for the processing of dsRNA to short RNA, and in specific organisms an RNA-dependent RNA polymerase, RdRP, crucial for siRNA amplification. ${ }^{19}$ From these initial discoveries the field has exploded with involvement in virology, genome stability, development and pathology. It has also offered novel experimental tools and an approach to therapy.

It is obvious that the implications of these discoveries have profoundly changed several paradigms in biology and medicine including the field of cell death and allowing not only a leap forward in knowledge, but also the development of novel technologies.

Cell Death and Differentiation is delighted to have the opportunity to bring this piece of history to its readers. This follows our previous special issue on the 2004 Nobel Prize Lectures (copyright The Nobel Foundation 2004. http:// nobelprize.org) awarded to Aaron Ciechanover, Avram
Hersko and Irwin Rose for the discovery of protein degradation. ${ }^{20-33}$ Once again, we are indebted to The Nobel Foundation for this exceptional opportunity to provide our readers with these uniquely personal accounts. Indeed, we hope our readers will perceive the human dimension underpinning these readings and that they will stimulate enthusiasm, perseverance and determination in a new generation of researchers.

1. Kornberg RD. Cell Death Differ 2007; 14: 1977-1980.

2. Mello CC. Cell Death Differ 2007; 14: 1981-1984.

3. Kornberg RD. Cell Death Differ 2007; 14: 1989-1997.

4. Mello CC. Cell Death Differ 2007; 14: 2013-2020.

5. Fire AZ. Cell Death Differ 2007; 14: 1998-2012.

6. Downs JA, Nussenzweig MC, Nussenzweig A. Nature 2007; 447: 951-958.

7. Crick F. Nature 1971; 234: 25-27.

8. Flanagan PM, Kelleher III RJ, Sayre MH et al. Nature 1991; 350: 436-438.

9. Kornberg RD. Science 1974; 184: 868-871.

10. Kornberg RD. Ann Rev Biochem 1977; 46: 931-954

11. Kornberg RD, Thomas JO. Science 1974; 184: 865-868.

12. Luger K, Mader AW, Richmond RK et al. Nature 1997; 389: 251-260.

13. Cramer P, Bushnell DA, Kornberg RD. Science 2001; 292: 1863-1876.

14. Gnatt AL, Cramer P, Fu J et al. Science 2001; 292: 1876-1882.

15. Fire A, Xu S, Montgomery MK et al. Nature 1998; 391: 806-811.

16. Romano N, Macino G. Mol Microbiol 1992; 6: 3343-3353.

17. Rocheleau CE, Downs WD, Lin R et al. Cell 1997; 90: 707-716.

18. Montgomery MK, Xu S, Fire A. Proc Natl Acad Sci USA 1998; 95: 15502-15507.

19. Cogoni C, Macino G. Nature 1999; 399: 166-169.

20. Hershko A. Cell Death Differ 2005; 12: 1158-1161.

21. Rose I. Cell Death Differ 2005; 12: 1162-1166

22. Ciechanover A. Cell Death Differ 2005; 12: 1167-1177.

23. Ciechanover A. Cell Death Differ 2005; 12: 1178-1190.

24. Hershko A. Cell Death Differ 2005; 12: 1191-1197.

25. Rose I. Cell Death Differ 2005; 12: 1198-1201.

26. Vaux DL, Silke J. Cell Death Differ 2005; 12: 1205-1207.

27. Ditzel M, Meier P. Cell Death Differ 2005; 12: 1208-1212.

28. Taylor RC, Adrain C, Martin SJ. Cell Death Differ 2005; 12: 1213-1217.

29. Cohen GM. Cell Death Differ 2005; 12: 1218.

30. Vandenabeele P, Orrenius S, Zhivotovsky B. Cell Death Differ 2005; 12: 1219-1224

31. Henderson CJ, Aleo E, Fontanini A et al. Cell Death Differ 2005; 12: 1240-1254.

32. Rossi M, Oberst A, Sayan AE et al. Cell Death Differ 2005; 12: 1255-1257.

33. Melino G. Cell Death Differ 2005; 12: 1155-1157. 